Ana-Maria DELIU

Faculty of Letters, Babeş-Bolyai University

Cluj-Napoca, Romania anamdeliu@gmail.com

Laura T. ILEA

Faculty of Letters, Babeş-Bolyai University

Cluj-Napoca, Romania airarle@yahoo.com

\title{
COMBINED AND UNEVEN FEMINISM: INTERSECTIONAL AND POST-CONSTRUCTIVIST TENDENCIES
}

Recommended Citation: Deliu, Ana-Maria, Ilea, Laura T. "Combined and Uneven Feminism: Intersectional and Post-Constructivist Tendencies.” Metacritic Journal for Comparative Studies and Theory 4.1 (2018): https://doi.org/10.24193/mjcst.2018.5.01

\begin{abstract}
Our study is meant to be read as an introduction to current networks of ideas and projects within the third-wave feminist theories. The first tendency that we identified is intersectional feminism, animated by the idea that feminism should not only speak to white middle-class women (Hamrouni, Maillé) and posing problems such as: seriality, equity and equality, postcolonialism. It seeks freedom from (intersected) oppressive social forces. The other tendency is an emerging postconstructivist, alternative materialist feminism that focuses on the freedom to act and know authentically as women (Grosz). It aims to render visible the relations between knowledge-production and corporeality (Harding). We would like to further suggest that the concept of combined and uneven development that has already been applied to a world-system analysis of literature (WREC) can also be insightful for understanding the development and co-existence of different feminisms today.
\end{abstract}

Keywords: intersectionalism, materialism, post-constructivism, situated epistemology, combined and uneven development 
When we started to outline the call for paper for this particular issue on contemporary feminist theory, we walked into a field full of tensions, splits and knots, continuities and contradictions. In the prevalent functioning model of feminism, there seems to be a linear progression between the first wave (focused on women's rights), the second wave (concerned with naturalising the equal distribution of power in public discourse), and the third wave, currently in the making, which is the focus of the current issue and the subject that we will dwell upon here. Sooner than assimilating feminism as a smooth and linear progression, we simply have to observe that the world we live in has progressed anything but smoothly and linearly. Eastern Europe has struggled to draw level with the Western socio-cultural transformations, the Orient is still in the phase that needs to address human rights, and a worldsystem analysis reveals that even in the so-called developed worlds there is combined and uneven development (WREC) calling for different actualisations of feminisms to respond to specific issues of real people living a particular moment of economic and socio-cultural development. Capitalism as a world-system is "the way in which capitalism is lived" (WREC 14), the coexistence of different realities and issues from radically different moments of history and development. If Warwick Research Collective aims to account for these tensions as they appear in literary productions, we suggest that feminist theory could also be described with greater specificity and without normativity in this organic way. Rather than a singular thread forming "waves," we now have an image of emerging networks of ideas and political projects. However, in order for these networks to be legible, we need to identify the prevalent theoretical drives that add up to the present dialogue in feminist theory.

The first tendency that we discerned seeks freedom from oppressive intersected forces, liberating projects that expand otherness to include race, class, and sometimes ethnicity. Intersectional feminism provides the tools for both civil activism and fierce theoretical discussions on ethics, pervasive social power dynamics, equity and equality, strategies of subversion, issues pertaining to the colonial history and so on. Diachronically, it can be seen as an evolution that marks the postcolonial and decolonial nodal points on its progression; synchronically, it can be visualised as a diagram that intersects gender studies, race studies and capitalist critiques. It poses that critical studies should offer a reading grid for the cultural codes that mediate our experience with the world. Working with these cultural codes that are now visible, it aims to repair social injustices and, in doing so, it always seeks 
systemic power relations that surpass gender and sex but are, nevertheless, strongly connected to these notions. There is a strong sense of social constructivism at work in intersectional feminism, that is, the idea that there is a socially determined overstructure of discourses that precedes the way we experience the world in a particular way (as women or as inhabitants of the undercommons). As feminists, the aim is therefore to identify and to make sense of the cluster of oppressive forces as to undermine the status quo that holds them together. This purpose echoes some interventions in our current issue, having Martine Delvaux write on the intricate relations between race and beauty in "Take Lemons and Make Lemonade: Serial Girls and the Question of Race," while Khanyile Mlotshtwa dwells on the current political context in Africa taking an anti-colonial stance in his "The Futility of Chasing Shadows of Patriarchal Liberation: The African National Congress's Women's League (ANCWL) and Anti-colonial Feminist Politics." We would like to suggest a point of reference in Naïma Hamrouni and Chantal Maillé (ed.), Le sujet du féminisme est-il blanc? Femmes racisées et recherche féministe (2015), where concepts such as multiculturalism, race, interethnic relations, and the sociology of immigration are spectralised through a sustained intersectional analysis.

The other tendency in current feminist theory shifts the focus from "freedom from" an oppressive other to "freedom to," in order to signal the departure from social-constructivist approaches to something else. Elizabeth Grosz puts this "something else" in terms of the materialist tradition of "freedom to" act in life according to our corporeality and our experiences as women (Grosz 140). A materialist feminism concerned with knowledge-production and corporeality emerges as an alter-feminism; it argues that the only way to escape oppression is to modify the knowledge-production system that allowed oppressions to thrive in the first place. Far from being sexually neuter, Western knowledge turns the male subject, its perspective and its experiences into the "neutral" point of inquiries, in other words into its "generic" stance of reference. Since the Socratic man, philosophers (and later psychoanalysts and even political theorists) have built upon dualisms taken as hard truths: on the one hand, Men-Rationality-Order-Ideal, on the other hand, Women-Affect-Chaos-Material'1. Order has to prevail over chaos, reason over the body, therefore it is crystal clear (and, indeed, as clear as an archetypal quest

\footnotetext{
${ }^{1}$ See Carl Gustav Jung, Modern Man in Search of a Soul, Harcourt, 1955. But also the way these ideas are uncritically perpetuated in the more recent Jordan B. Peterson, Maps of Meaning: The Architecture of Belief, Routledge, 1999.
} 
to self-realisation) that men should dominate women. It might seem counter-intuitive now that feminists turn their energy towards philosophies and politics of affect, new materialisms and theories of chaos, but their doing so does not mean that they accept an essentialist link that binds women to affect-chaos-material; instead, they turn their theoretical energy towards these notions to scrutinise what has been systematically neglected or "forgotten" in knowledge-production. A point of reference in this on-going project is Sandra Harding and Merril B. Hintikka (ed.), Discovering Reality. Feminist Perspectives on Epistemology, Metaphysics, Methodology, and Philosophy of Science (Kluwer Academic Publishers, 2004). Their volume aims to abridge the distance between nature and culture (hence the post-constructivist label) while withholding a strong ontological rootedness: reality has been distorted by idealist philosophies and their network of discourses, therefore the feminist aim is to restore the neglected - bodies, affects and a shared agency with human and nonhuman forces (hence the critique of the orderly Enlightenment project to aggressively tame and exploit nature). A corporeal reality precedes discourses, as opposed to merely being constructed by society. The later posthumanist approaches wanted to destabilise this nature/culture paradigm altogether and to move toward a naturewith-culture theory that will inspire the current approaches in feminism. In our current issue, the materialist feminist approaches have been put in relation to fiction, with Alina Preda writing "An Agential Realist Approach to Posthumanist Relational Subjectivity in Jeanette Winterson's The Stone Gods" and Cristina Diamant's "A Kynical View on Corporeality: Jeanette Winterson's Non-Philosophy in Written on the Body", while Anna Specchio writes on "Eutopizing the Dystopia. Gender Roles, Motherhood and Reproduction in Murata Sayaka's Satsujin Shussan." A distantreading approach is to be found in Daiana Gârdan's "The Great (Female) Unread. Romanian Women Novelists in the First Half of the Century: A Quantitative Approach," where feminist theories inform the background of a quantitative analysis of the Romanian novel.

\section{Intersectionality - A Method of Decentering the Universal Woman}

The main critique that intersectional feminism articulates is the seriality of the dominant feminist model, the idea that the subject of its discourse is the white (middle-class) woman, erasing any particularities in a utopic quest towards a unifying theory. This perspective was intensely debated during an event that took place in 
Montreal in April 2017, as part of the international literature festival Metropolis Bleu, entitled Feminism: a mandatory passage? (Le féminisme: un passage obligé?). The referential theories and sources of this debate are to be found in two books, namely Le sujet du féminisme est-il blanc? Femmes racisées et recherche féministe (2015) and Les Blancs, les Juifs et Nous. Vers une politique de l'amour révolutionnaire (2016), especially through the lenses of decolonial feminism. One of the first issues in the agenda of the aforementioned event was understanding how intersectionality alters the image of the "universal woman" (thus undermining precisely its universality) in regards to the question of beauty. In most feminist writings, beauty is considered to be a sign of oppression, of confinement into a burqa of flesh (Arcan). On the contrary, to talk about the beauty of a woman of colour means to recognise the liberating value of beauty, as well as the range of its diversity. Discussing the veil and the question of beauty, the hegemonic feminism transpires as racist and contradictory:

The traditional feminism criticises the norms of beauty which reduce women to their body. Or, in the case of the black woman, the affirmation of beauty is fundamental because racism denied beauty to black bodies. Thus, to claim a body and a beauty for these women means also to affirm their liberation and not their alienation ${ }^{2}$ (Bouteldja, Le Devoir).

If beauty is a central issue in the definition and demarcation of feminist questions in regards to the Western and the decolonial model, then the idea of a "racialised woman" - a woman whose status and social role is mostly and sometimes exclusively considered through the notion of race - is even more problematic. Because the first question it raises is whether this concept is a genetic or a constructed one. Once the term "racialised woman" (femme racisée) appears, it immediately signifies a political position. Houria Bouteldja - a radical proponent of a racial critique of feminism insists on terminology, and clarifies the concept in two different contexts, namely the colonial France and the multicultural Quebec. In her controversial, but intriguing Les Blancs, les Juifs et nous, she does not actually use the concept of "racialised woman" but that of "indigenous woman" (Bouteldja 71), which exposes from the very start the

2 "Le féminisme traditionnel critique les normes de beauté qui réduisent les femmes à leur corps. Or, chez la femme noire, l'affirmation de la beauté est fondamentale parce que le racisme a nié la beauté du corps noir. Du coup, revendiquer un corps et une beauté pour ces femmes, c'est aussi affirmer une libération et non pas une aliénation.” (Bouteldja, Le Devoir, 25 April, 2017. Our translation.) 
core issues of colonial history. The "indigenous" inside the Republic is the one who is seen as an under-citizen, designed by her social and political status. Moreover, the author insists on the fact that the racial issue has double implications: for those to whom it is imposed, and for those who are imposing it, for the oppressed and for the oppressors. In this sense, whiteness is racialised.

Talking about racialised women in Quebec signifies from the very beginning making a political statement, as well as taking a political stance. Usually, non-white people have been neutrally designated as diverse, as immigrants, in order to situate them in connection to others as well as to their own status. The book Le sujet du féminisme est-il blanc? talks about ordinary women who find themselves in racialised positions. Consequently, the theoretical framework implies the normativity of whiteness. The context of Quebecer culture and society is particularly sensitive to normativity standards at more than one level: the traditional marginality of Quebecers in the context of the Anglophone dominance seems quite peculiarly overcompensated by their becoming the norm of a dominant society to other subordinate categories. Thus the inquiry regarding what it means to be "the other," racially different and diminished, does not have a long history in the common representation in Quebec.

On the contrary, the most common term within the Quebec society that used to describe "the other" is "multiculturalism," a mild approximation of diversity (Hamrouni 57). Multiculturalism is interpreted in terms of acknowledgement (reconnaissance) and wealth distribution, but it does not take into account a radical term, namely dehumanization, derived from discriminatory laws devised for the benefit of a white subject. As such, most criticism of multiculturalism points to its inability to truly acknowledge difference. When understood exclusively in cultural terms, multiculturalism obliterates and renders invisible the experience of racism (violence, dehumanization, postcolonial immigration). Hamrouni is very radical in this respect, claiming that the government position represented by Justin Trudeau, who recommends integration as an advantage to society, and multiculturalism as celebration of diversity, keeps silent about the fact that integration becomes a duty towards those who have been displaced, disinherited, misjudged and misrepresented by colonial politics. Thus, integration is not a gift, but reparation, a matter of justice. According to this author, the very introduction of the term "racialised woman" 
represents a progress in terms of public discourse, because it circumscribes this category as being dislodged from the normative discourse.

In France, on the other hand, the resistance to the concept of "racialised woman" comes from the paradigm of the Nation State. Here, neutrality rather than integration results in deep social division. To the neoliberal, indigeneity is deviant, anormative. According to James Baldwin (La Prochaine Fois, le feu, 1996), extensively quoted by intersectional feminists, in order to redefine family and sexuality within a different model, powerful values such as equality, emancipation and freedom have to be decentred. Baldwin issues a warning against accusing the individuals instead of systems, where the core of the matter really lies. This is a powerful claim, since it can be applied to different occurrences of feminism: in most cases, individual inequalities, discrepancies and injustices are enabled by the inherent structure of specific systems. He also claims that a redefinition of blackness needs to be reconsidered in the Western world, through the questioning of the very notions of imperialism and nation.

Intersectionality addresses also the weaknesses of the liberal ideal. The first critique concerns the notion of equality. Equality is of course very important, and battles should be fought for its generic ideal, but the liberal society so far is unable to discern intra-communal inequalities. The second claim relates to the idea of meritocracy, based on the assumption that everyone can achieve self-accomplishment within a group, while following a homogenous model, namely that of a "universal woman." Of course, these kinds of critiques were already formulated before intersectionality. One could, in response, argue that the neoliberal structures encourage the dispersion of the internal micro groups and their subsequent aggregation according to multiple logics, therefore creating space for the visibility of marginal groups and thus serving intersectionality itself.

Following all these fault lines, one could straightforwardly affirm that intersectionality decentres the "universal woman." This decentred model presupposes a more precise description of different relations to power, and the acknowledgement that there are more particular groups of women within the dominant model. The most important agenda is thus to identify those power relationships deviating from the exclusive patriarchal model imposed by Simone de Beauvoir in Le Deuxième Sexe in 1949. There is not only one model of power relations. Quite the contrary, one should infer that an entire spectrum of power relations and intersectionality is able to 
account for this complexity. If the patriarchal model imposes oppression on women in general, there are certain categories of women who have privileges over other categories and they exert the same hegemonic power. So, one could underline the fact that intersectionality should in principle be able to render the complexity of the power relations within the dominant model, and thus gain political value.

Therefore, one could of course inquire whether this type of movement would not engender a certain kind of nostalgia towards the "subaltern?" If hegemonic women are at that point vilified, why would we not allow them the capacity to embrace the subaltern? If we decentre power relations, then the central narrative of feminism should also be decentred, due to internal incompatibilities. Feminism circulates under different narratives, which are no longer hegemonic. As Houria Bouteldja affirms in a text written for Le Devoir:

The French intelligentsia is nostalgic about its old ideas and refuses to hear the new forms of thought that upset the ready-made thinking and undermine dogmas and truths... Feminism is defined in relation to the condition, the past, and the history of the white woman... But women who bear a colonial past are elsewhere. They are not only crushed by patriarchy. They are also crushed by their social condition, by the extreme poverty in general, and crushed by racism. They cannot envisage the fight in the same way as white women do33 (Bouteldja Le Devoir 2).

In this context, intersectionality exposes the fallacy of multiculturalism, which involves a certain conceptual vacuity - either in its liberal form, which imposes the reasonable accomodations 4 ; or in its Neohegelian form of fight for acknowledgement. None of these models challenges dehumanisation - a notion proposed by the critical theorists of race: what the racialised women want is not only to benefit from the same rights or to have their difference recognised or celebrated (as it is often the case in the advertisements diversity in Quebec), but that their dehumanisation stops. Dehumanisation is an extremely material condition, involving

\footnotetext{
3 "L'intelligentsia française se terre dans la nostalgie de ses idées anciennes et refuse d'entendre les pensées nouvelles qui chamboulent le prêt-à-penser, qui ébranlent les dogmes et les vérités... Le féminisme se définit par rapport à la condition, au passé, à l'histoire de la femme blanche... Or, les femmes issues d'un passé colonial sont ailleurs. Elles ne sont pas seulement écrasées par le patriarcat. Elles sont aussi écrasées par leur condition sociale, de pauvreté extrême en général, écrasées par le racisme. Elles ne peuvent envisager la lutte de la même manière que les femmes blanches" (Our translation).

4 Also known as "accommodements raisonnables," a typical manner of negotiation for a multicultural society as it is the case of the Quebec society.
} 
at the same time notions and realities such as evacuation, denigration, minoritisation, stigmatisation, and lack of credit. These tensions are at the core of the redefinition of the intersectional feminist model, as debated in a 2014 conference at Concordia University in Montreal, whose outcome is precisely the book Le sujet du féminisme est-il blanc? Femmes racisées et recherche féministe.

One could reinforce the feminist critique towards institutions supported by the dominant group and their epidemic injustices by underlining the manner in which different political parties consider immigration in terms of the integration of those people that "choose" to come "to us" in order to secure a happier and more prosperous future for their children. This perspective obliterates the colonial history witnessed by dominated groups and presents as a privilege the "happy settlement," when it represents, in fact, a repercussion of exploitation, of abuses and violence that colonial history imposed on different populations. If one takes history of domination seriously, one is perhaps obliged to consider hospitality towards these oppressed populations as being a manner of repairing the injustice imposed onto them by the colonial power, whose consequences are still visible today.

As a result, the term "race", focusing on social implications and the necessity of formulating policies that would be sensitive to it, involves positive action. Through concrete measures of political action, one does not presuppose assimilating or integrating minorities within structures imposed by the dominant group and their privileges but, on the contrary, raising awareness related to the perspective of minorities in order to criticise the actual functioning of certain institutions: positive action does not have as an objective the celebration of diversity or the assimilation of the racialised women, but rather giving a voice to these groups and allowing them to criticise, raise issues and take part in the reconfiguration of institutions.

In these conditions, the notion of "structural racism" is more adequate to the context described. It transfers the debate to the modalities through which contemporary media tends to avoid responsibility, by focusing on a discriminatory, depersonalized system of discourses. Injustice and structural racism allow us to understand that, if institutions impose forms of discrimination, they do so through a general, allegedly neutral framework.

In the context of institutions responsible for the unbalances of power, a sensitive issue treated by the above mentioned activists and researchers is the problem of masculine violence. It is straightforwardly affirmed that this would be a 
direct consequence of a castrating society: policemen kill men, men kill women, in a perfect action-reaction model. An original humiliation creates solidarity between men of colour and women of colour. Whereas "white feminism" is prone to combat men, the intersectional approach is mostly directed towards eradicating the three-fold oppression of race, gender and class. Because non-white women are related to nonwhite men, their solidarity is expressed in terms of fighting racism. Discrimination and oppression are part of a general schema of violence, where women are experiencing the violence of state and a surplus of violence due to racism. Of course, it is obvious that this radical claim could easily reinstate a new normativity, by underlining the virtues of an orthodox, mono-racial position and negating the value of the individual option, able to overcome race.

As a consequence, the first of the strategies to counteract oppression should consist in reinforcing solidarity with dominated men, by refusing their dehumanisation. This is also relevant when talking about sexuality. Having a long history of associating black men with bestiality and the unbound "Dionysian" figures, black men have been reduced to the irrational, the bestial, and the "hipster", similarly to how women have been essentially bound to the affect-chaos-material scheme that we discussed in the first part. The outcome of this counter would be the normalisation of sexuality, equality and the clear affirmation that the sexuality of the man of colour is not bestial by nature.

Taking into account the above discussions and analyses, one could doubtlessly affirm that the battle at the core of racial feminism is three-pronged, involving feminist, anti-capitalist and anti-racial positions, reacting against a triple oppression. As a result, Black, Arabic, Roma and all other minority women could in all legitimacy reclaim dignity based on intersectional stances, by manifesting against police crimes directed against men of their own communities. Their core presupposition is the affirmation according to which racism imposed to dominated men is resurging in various forms against women.

Reflections on violence are thus a reservoir full of consequences in France, Quebec but also in other territories where preconceived ideas of non-reflected interference between race and violence are dominant. It involves the fact that,

5 See the influential essay by Norman Mailer, "The White Negro": "With this possible emergence of the Negro, Hip may erupt as a psychically armed rebellion whose sexual impetus may rebound against the anti-sexual foundation of every organized power in America" (294-5). This was a revolutionary essay written in the context of the clashes between the hipster, beat culture and the mainstream society in 1957, that nevertheless fell into an essentialist grid that would bound blackness and bestiality. 
whenever crimes are perpetrated by white men, society has a "natural" tendency towards compassion, passion being the main argument invoked. What is disquieting in the general take on violence is that white men and women are equally violent. But their violence mostly benefits from narratives of their various motivations, mitigating circumstances and contexts, whereas in the case of men and women of colour it is constantly explained by race. The "racialised person" is then violent by definition. An example related to this is the extended debate concerning crimes of honour, ambiguous in the sense that on the one hand it banishes unacceptable practices but on the other hand it focuses on the moral superiority over another culture, whose norms and codes of conduct are inherently incompatible with the norms and codes of conduct of a "civilised society." The point of view of a consistent intersectional approach considers that, before any tentative valuation of practices, the presupposition of an inferior culture should be avoided in the first place.

As a conclusion to all these debates related to race, racialised women, and the genealogy of violence, one could affirm that the main asset of the intersectional approach consists in unlearning the double standard (le double regard) at the very core of feminism. It also consists in undoing the general rules of institutions that engender injustice and dehumanisation, and enlarging the categories through which multiculturalism is conceived, so that it no longer obliterates and renders invisible the experience of racism.

\section{"Freedom from" and "Freedom to." Materialist and Post-constructivist Shapes of Feminism}

As the feminist discussions on (intersectional) social power dynamics seem to intensify, some feminists choose to turn their energy from liberating projects (that seek "freedom from" an oppressive otherness, often in the form of sex, but more recently intersected with race, ethnicity or nationality) to contributing to the knowledge-production ("freedom to" act, create, and, broadly put, to shape the future authentically as a woman). But what is wrong with the current way knowledge is created and what does it have to do with feminism? The epistemic model cemented in Enlightenment seems to offer social protection in the form of human rights and an education theoretically based on reason. Nevertheless, as women scholars attempted to account for their experiences as social agents, as culture producers and as "bare 
life"6 representatives, it has become clear that there is little to no reliable knowledge to add to, and that, in fact, knowledge is gendered. Here is how a call for contributions for Discovering Reality. Feminist Perspectives on Epistemology, Metaphysics, Methodology, and Philosophy of Science (collective book edited by Sandra Harding and Merrill B. Hintikka as early as 1983), sounds:

In the last decade feminist thinkers have provided brilliant critiques of the political and social beliefs and practices of patriarchal cultures. But less attention has been given to the underlying theories of knowledge and to the metaphysics which mirror and support patriarchal belief and practice. Are there - can there be - distinctive feminist perspectives on epistemology, metaphysics, methodology and philosophy of science? (ix)

This is how a feminist theoretical apparatus concerned with how knowledge is made and how it is sensitive to gender and corporeality emerged. Firstly, we have to recognise that the realm of "hard facts" and abstractions is not sexually neuter or indifferent: the "universality" that philosophies of reason claim when talking about humans is based on a (socio-culturally determined) masculine norm. For example, philosopher and feminist Lynda Lange exposed the sexist bias in Aristotle (drawing from a solid corpus including Eudemian Ethics, De Generatione Animalium, De Partibus Animalium). The famous Aristotelian stance, that "Man is a rational animal," is no longer taken seriously or ad litteram by any philosopher that is not a male supremacist, and it is dismissed as something not worth talking about by either 1) placing the issue on wording, as if Aristotle meant to say "the human being", or 2) placing the issue on the historical context marked by profoundly inscribed sexism and conserving, nevertheless, the "universality" of Aristotelian thought. As Lange argued, Aristotle's views on sexual differences are not incidental to his philosophy and cannot be ignored, since there are assumptions about women's inferiority tightly interwoven with his views on ethics and politics (Lange 1-15). The theory of generation, its biology, is inseparable from the "generic premise" (Lange 8), a metaphysical assumption that superimposes a biological and a social function. "For example, if it is a matter of fact that gestation occurs in a (socially) inferior being, this method makes it natural to assume that gestation is itself an inferior function to impregnation"

\footnotetext{
6 "Man is the living being who, in language, separates and opposes himself to his own bare life"
} (Agamben 8). We use "bare life" for the expressive opposition of life to culture. 
(Lange 9). Moreover, Aristotle observes in De Generatione Animalium that what "nature endows with a smaller portion of heat is weaker" and immediately adds that "it has already been stated that such is the character of the female" (726 b 32, qtd. in Lange 9). It therefore follows, once again, that the male is superior to the female because (and this is the assumption presented as a "generic premise") males have hotter blood (648 a 10-5, qtd. in Lange 9). Similarly to the intersectional approach, the drive is not to intend ethical processes to individuals, but to find the fundamental and systemic issues that here become issues interwoven with knowledge.

Surely, today we shy away from archaic biological accounts; after all, Aristotle had neither a thermometer, nor the methodology to measure and compare the heat of the blood (although, if he had, it would have not served to show equality, since it fails the "generic premise" and so it becomes irrelevant to knowledge-production). As Elizabeth V. Spelman argues, the same reasoning is applied to metaphysics: "in the Politics Aristotle turns to the constitution of the soul in order to justify his view that certain classes of beings are by nature to rule over other classes" (Spelman 21). We now have scientific tools to argue in favour of social hierarchies. Notions such as scarcity and competition, which make for a large part of Darwinist natural sciences, are uncritically valued as premises to natural hierarchies and extrapolated to social hierarchies. The feminist quest is once again to contextualise these premises, to examine how Darwinism intersects the social and political ideology, as well as Victorian precepts about the dynamics between sexes. One of the earliest observations about the social aspect of Darwin's theory was made only three years after the publication of The Origin of Species, by Karl Marx, in a letter to Friedrich Engels:

The whole Darwinist teaching of the struggle for existence is simply transference from society to living nature of Hobbes's doctrine of "bellum omnium contra omnes" and of the bourgeois-economic doctrine of competition together with Malthus's theory of population. When this conjurer's trick has been performed...the same theories are transferred back again from organic nature into history and now it is claimed that their validity as eternal laws of human society has been proved (Sahlins 101-2).

The myth is that we simply take examples of scarcity and competition from the natural world in order to legitimise a societal patriarchal capitalist practice that works with the very same notions: scarcity and competition. In fact, Darwin's theories 
of evolution are profoundly marked by Malthus' social theory of population, a theory that historically spurred as a counter-reaction to the English "poor laws" - Malthus showing concern for the decline of bourgeoisie and aristocracy under the proto-social welfare legislations which would enable the poor and unfit to survive and procreate (Harding 50-1, 75-6). Moreover, as Michael Gross and Mary Beth Averill suggest, the scientific discourse also carried gendered social expectations:

This alienated perception of nature which emphasizes its parsimony may derive largely from male socialization to strive against others and to manipulate nature in the world of work; and it may little correspond with women's traditional experience, in western history, in the realm of family and home, where the main emphasis is upon relationship (Gross, Averill 76).

It is time to sincerely ask ourselves if scarcity and competition are in fact the principles that ensure thriving in the natural world (in a Darwinist later reading, through the "survival of the fittest"). Feminist scientists and epistemologists have been asking this question with, as far as this argument goes, predictable results: Toward an Anthropology of Women (Reiter) unveiled the Victorian preconceptions at the heart of the evolutionary discourses, Grosz and Averill made the compelling argument that plenitude and cooperation are equally insightful principles in understanding how a species evolves and how life thrives (Grosz, Averill 71-95), Murray Bookchin showed that ecosystems cannot be meaningfully described in terms of hierarchies (Bookchin 90-5).

The production of knowledge is always historical, always contextual, even, and maybe, especially, when it claims universality, by leaving a blind spot in regard to the conditions that generated it. The materialist feminist quest is precisely to track this intricate network of nature-society knowledge-production and to further show how corporeality, our grounding in the world, affects and precedes discourses. Without falling into simplistic essentialisms such as "women are cooperative by nature and men are competitive by nature," we nevertheless have to recognise that corporeality has much more to offer in terms of interpreting the world. Talking about something as "neutral" as competition in theories of evolution, we also have to talk about how feminine bodies were perceived in the nineteenth century, and how order (the survival of the fittest through male bodies) had to prevail once again over chaos (the 
reality that there is much randomness in the process of reproduction, associated with female bodies):

As men were engaging in political struggle with women, so, in the realm of evolutionary thought, men installed competition as the force which imposes order on the chaos they perceived in the process of reproduction, which they associated with women. Evolution and natural selection, as products of nineteenth century thought, coincide with other reflections of men's anxiety about women, most plainly displayed in their preoccupation with her reproductive ability: her uncontrolled sexuality, her (“pathological”) reproductive physiology, even her (hysterical) psychology (Harding 81).

So what does this "freedom to" mean? In the light of these arguments, it means to authentically and legitimately express a woman's experience and creativity, the freedom to feel at home in the world. We can have "freedom from" oppressive forces that impose sexist laws that affect women and their bodies and still have our experiences as women forgotten, not because of amnesia or patriarchal conspiracies to keep women silent, but simply because any attempt to contribute to the knowledge-production authentically as a woman raises insurmountable tensions. When the man experience is mistaken as the "human experience," not only are the resulting theories, concepts and methodologies unethical, but also fundamentally distorted: only partial human experience, only partially understood; the experience of men from the perspective of men. However, simply inverting the representation in knowledge will not suffice. Posthumanism does not exclude the human subject, but, on the contrary, it aims to understand humans with greater specificity as they appear in complex human and non-human networks, in a nature-with-culture paradigm. Similarly, the materialist feminist aim is not to exclude men from knowledge, but precisely to understand the human subject - which is the subject of this feminism rather than the particularity of being a woman - with greater specificity.

In this vein, we consider that a combined and uneven development in the extremely bifurcated field of feminism is one of the best modalities to describe different needs and theories that would cover a spectrum as distinct and unbalanced as it is highlighted by the nodal points of the postcolonial and decolonial history; by an intersection of gender studies, race studies, and capitalist critiques; by the presupposition of a socially determined over-structure of discourses that precedes 
our experience of the world; by a form of departure from social-constructivist approaches to a materialist and corporeal knowledge-production; by a process intended to fundamental and systemic issues that are interwoven in the network of knowledge; last but not least, by tracing a counter model of plenitude and cooperation that would possibly remediate the scarcity and competition evolutionary model. We do not propose an evolutionary model, but rather an uneven development model, where all the above-mentioned tendencies reinstate different forms of materialist, corporeal, and vulnerable posits that at the same time subvert and gentrify the all-encompassing dogma of the universal human.

\section{References}

Arcan, Nelly. Burqa de chair. Éditions du Seuil, 2011.

Baldwin, James. La Prochaine Fois, le feu. Gallimard, 1996.

Bookchin, Murray. The Ecology of Freedom: The Emergence and Dissolution of Hierarchy. AK Press, 2005.

Bouteldja, Houria. Le Devoir, 25 April 2017. Accessed 12 June 2018, https://www.ledevoir.com/lire/497153/metropolis-bleu-houria-bouteldja-lessayiste-qui-derange.

Bouteldja, Houria. Les Blancs, les Juifs et Nous. Vers une politique de l'amour révolutionnaire. La Fabrique, 2016.

De Beauvoir, Simone. Le Deuxième Sexe. Gallimard, 1949.

Gross, Michael, Mary Beth Averill. „Evolution and Patriarchal Myths of Scarcity and Competition." Harding and Hintikka, pp. 71-97.

Grosz, Elizabeth. "Feminism, Materialism, and Freedom." New Materialisms. Ontology, Agency, and Politics. Diana Coole, Samantha Frost (ed.). Duke UP, 2010.

Hamrouni, Naïma. Chantal Maillé (ed.). Le sujet du féminisme est-il blanc? Femmes racisées et recherche féministe. Les Éditions du Remue-ménage, 2015. 
Harding, Sandra, Merril B. Hintikka (ed.). Discovering Reality. Feminist Perspectives on Epistemology, Metaphysics, Methodology, and Philosophy of Science. Kluwer Academic Publishers, 2004.

Lange, Lynda. „Woman Is Not a Rational Animal: On Aristotle's Biology of Reproduction." Harding and Hintikka, pp. 1-17.

Mailer, Norman. "The White Negro." Postmodern Voices: AP English Language and Composition, http://www.dhs.fjanosco.net/Documents/TheWhiteNegro.pdf. Accessed 15 June 2018.

Reiter, Rayna R. Toward an Anthropology of Women. Monthly Review Press, 1975.

Sahlins, Marshall. The Use and Abuse of Biology. University of Michigan Press, 1976.

Spelman, Elizabeth V. „Aristotle and the Politicization of the Soul.” Harding and Hintikka, pp. 17-31.

WREC (Warwick Research Collective). Combined and Uneven Development. Towards a New Theory of World-Literature. Liverpool University Press, 2015 . 